NBER WORKING PAPER SERIES

\title{
INFLATION TARGETING IN EMERGING MARKET COUNTRIES
}

Frederic S. Mishkin

Working Paper 7618

http://www.nber.org/papers/w7618

NATIONAL BUREAU OF ECONOMIC RESEARCH 1050 Massachusetts Avenue

Cambridge, MA 02138

March 2000

Prepared for AEA Papers and Proceedings, May 2000 at the session "Inflation Targeting" held at the ASSA meetings, Boston Mass., January 7, 2000, 2:30 p.m. I thank Miguel Savastano for his helpful comments. The views expressed in this paper are exclusively those of the author and not those of Columbia University or the National Bureau of Economic Research.

(C) 2000 by Frederic S. Mishkin. All rights reserved. Short sections of text, not to exceed two paragraphs, may be quoted without explicit permission provided that full credit, including (C) notice, is given to the source. 
Inflation Targeting in Emerging Market Countries

Frederic S. Mishkin

NBER Working Paper No. 7618

March 2000

JEL No. E5

\section{$\underline{\text { ABSTRACT }}$}

This paper outlines what inflation targeting involves for emerging market/transition countries and discusses the advantages and disadvantages of this monetary policy strategy. The discussion suggests that although inflation targeting is not a panacea and may not be appropriate for many emerging market countries, it can be a highly useful monetary policy strategy in a number of them.

Frederic S. Mishkin

Graduate School of Business

Uris Hall 619

Columbia University

New York, NY 10027

and NBER

fsm3@columbia.edu 
The unhappy experience of Latin American and East Asian countries with pegged exchange rate regimes who subsequently found themselves in deep financial crises in the 1990s has led emerging market economies to search for alternative nominal anchors. (I am including transition countries in Eastern Europe and the former Soviet Union in the emerging market category.) Targeting inflation, a monetary policy strategy which has been successfully used by a number of industrialized countries, has thus become an increasingly attractive alternative that has been adopted by a growing number of emerging market countries, including Chile, Brazil, the Czech Republic, Poland and South Africa. In this paper, I outline what inflation targeting involves for these countries and discuss the advantages and disadvantages of this monetary policy strategy. The bottom line is that although inflation targeting is not a panacea and may not be appropriate for many emerging market countries, it can be a highly useful monetary policy in a number of them

\section{I.}

\section{What Is Inflation Targeting?}

Inflation targeting is a monetary policy strategy that encompasses five main elements: 1) the public announcement of medium-term numerical targets for inflation; 2) an institutional commitment to price stability as the primary goal of monetary policy, to which other goals are subordinated; 3) an information inclusive strategy in which many variables, and not just monetary aggregates or the exchange rate, are used for deciding the setting of policy instruments; 4) increased transparency of the monetary policy strategy through communication with the public and the markets about the plans, objectives, and decisions of the monetary authorities; and 5) increased 
accountability of the central bank for attaining its inflation objectives. The list should clarify one crucial point about inflation targeting: it entails much more than a public announcement of numerical targets for inflation for the year ahead. This is important in the context of emerging markets' countries because many of them routinely reported numerical inflation targets or objectives as part of the government's economic plan for the coming year, and yet their monetary policy strategy should not be characterized as inflation targeting, which requires the other four elements for it to be sustainable over the medium term.

II.

\section{Advantages of Inflation Targeting}

Inflation targeting has several advantages as a medium-term strategy for monetary policy. In contrast to an exchange rate peg, inflation targeting enables monetary policy to focus on domestic considerations and to respond to shocks to the domestic economy. In contrast to monetary targeting, another possible monetary policy strategy, inflation targeting has the advantage that a stable relationship between money and inflation is not critical to its success: the strategy does not depend on such a relationship, but instead uses all available information to determine the best settings for the instruments of monetary policy. Inflation targeting also has the key advantage that it is easily understood by the public and is thus highly transparent.

Because an explicit numerical target for inflation increases the accountability of the central bank, inflation targeting also has the potential to reduce the likelihood that the central bank will fall into the time-inconsistency trap. Moreover, since the source of timeinconsistency is often found in (covert or open) political pressures on the central bank to undertake overly expansionary monetary policy, inflation targeting has the advantage of 
focusing the political debate on what a central bank can do in the long-run -- i.e., control inflation -- rather than what it cannot do -- raise output growth, lower unemployment, increase external competitiveness-- through monetary policy. For inflation targeting to deliver these outcomes, there must exist a strong institutional commitment to make price stability the primary goal of the central bank. This is particularly important in emerging market countries which have often had a past history of monetary mismanagement. The institutional commitment involves legislative support for an independent central bank whose charter ought to contain two key features: 1) sufficient insulation of the policymaking board of the central bank from the politicians--with members of the government excluded and the members of the board appointed to long terms and protected from arbitrary dismissal; and 2) giving the central bank full and exclusive control over the setting of monetary policy instruments. The institutional commitment to price stability also requires that the central bank be given a mandate to have price stability as its primary goal, making it clear that when there is a conflict with other goals, such as exchange rate stability or promotion of high employment, price stability must be accorded the higher priority.

Inflation-targeting regimes also put great stress on the need to make monetary policy transparent and to maintain regular channels of communication with the public; in fact, these features have been central to the strategy's success in industrialized countries. As illustrated in Frederic Mishkin and Adam Posen (1997), and in Ben Bernanke, Thomas Laubach, Frederic Mishkin and Adam Posen (1999), inflation-targeting central banks have frequent communications with the government, and their officials take every opportunity to make public speeches on their monetary policy strategy. Inflation targeting central banks have taken public outreach a step further: they publish Inflation Report-type documents (originated by the Bank 
of England) to clearly present their views about the past and future performance of inflation and monetary policy.

Another key feature of inflation-targeting regimes is that the transparency of policy associated with inflation targeting has tended to make the central bank highly accountable to the public. Sustained success in the conduct of monetary policy as measured against a preannounced and well-defined inflation target can be instrumental in building public support for an independent central bank, even in the absence of a rigidly defined and legalistic standard of performance evaluation and punishment.

\section{III. Disadvantages of Inflation Targeting}

Critics of inflation targeting have noted seven major disadvantages of this monetary policy strategy. Four of those disadvantages -- that inflation targeting is too rigid, that it allows too much discretion, that it has the potential to increase output instability, and that it will lower economic growth-- have been discussed in Mishkin (1999) and in Bernanke, et al. (1999), and are in reality not serious objections to a properly designed inflation targeting strategy which is best characterized as "constrained discretion". The fifth disadvantage, that inflation targeting can only produce weak central bank accountability because inflation is hard to control and because there are long lags from the monetary policy instruments to the inflation outcome, is an especially serious one for emerging market countries. The sixth and seventh disadvantages, that inflation targeting cannot prevent fiscal dominance, and that the exchange rate flexibility required by inflation targeting might cause financial instability, are also very relevant in the emerging market country context. 
In contrast to exchange rates and monetary aggregates, the inflation rate cannot be easily controlled by the central bank; furthermore, inflation outcomes that incorporate the effects of changes in instruments settings are revealed only after a substantial lag. The difficulty of controlling inflation creates a particularly severe problem for emerging market countries when inflation is being brought down from relatively high levels. In those circumstances, inflation forecast errors are likely to be large, inflation targets will tend to be missed, and it will be difficult for the central bank to gain credibility from an inflation targeting strategy, and for the public to ascertain the reasons for the deviations. This suggests that, as noted by Paul Masson, Miguel Savastano and Sunil Sharma (1997), inflation targeting is likely to be a more effective strategy if it is phased in only after there has been some successful disinflation.

One other factor affecting inflation controllability that is especially relevant in the emerging market context is the (at times large) incidence of government-controlled prices on the index used to compute headline inflation. As a result inflation targeting may demand a high degree of coordination between monetary and fiscal authorities on the timing and magnitude of future changes in controlled prices or, alternatively, the exclusion of controlled prices from the targeted price index, as in the Czech Republic.

A sixth shortcoming of inflation targeting is that it may not be sufficient to ensure fiscal discipline or prevent fiscal dominance. Governments can still pursue irresponsible fiscal policy with an inflation targeting regime in place. In the long run, large fiscal deficits will cause an inflation targeting regime to break down: the fiscal deficits will eventually have to be monetized or the public debt eroded by a large devaluation, and high inflation will follow. Absence of outright fiscal dominance is therefore a key prerequisite for inflation targeting, and the setting up of institutions that help keep fiscal policy in check are crucial to the success of 
the strategy (Masson et al., 1997) Similarly, a sound financial system is another prerequisite for successful inflation targeting because when financial systems blow up, there is typically a surge in inflation in emerging market countries. However, as pointed out in Frederic Mishkin and Miguel Savastano (1999), a sound financial system and the absence of fiscal dominance are also crucial to the sustainability and success of any other monetary policy strategy, including a currency board or full dollarization. Indeed, inflation targeting may help constrain fiscal policy to the extent that the government is actively involved in setting the inflation target (including through the coordination of future adjustments to government-controlled prices).

Finally, a high degree of (partial) dollarization may create a potentially serious problem for inflation targeting. In fact, in many emerging market countries the balance sheets of firms, households and banks are substantially dollarized, on both sides, and the bulk of long-term debt is denominated in dollars (Guillermo Calvo, 1999). Because inflation targeting necessarily requires nominal exchange rate flexibility, exchange rate fluctuations are unavoidable. However, large and abrupt depreciations may increase the burden of dollar-denominated debt, produce a massive deterioration of balance sheets, and increase the risks of a financial crisis along the lines discussed in Mishkin (1996). This suggests that emerging market countries cannot afford to ignore the exchange rate when conducting monetary policy under inflation targeting, but the role they ascribe to is should be clearly subordinated to the inflation objective. It also suggests that inflation targeting in partially dollarized economies may not be viable unless there are stringent prudential regulations on, and strict supervision of, financial institutions that ensure that the system is capable of withstanding exchange rate shocks.

\section{IV.}

\section{Lessons from Recent Experience}


The earliest example of an emerging market country adopting inflation targeting is Chile, which in 1990 , with the inflation rate in excess of $20 \%$, first started to announce an inflation objective in September for the twelve-month inflation rate ending in December of the following year. ${ }^{1}$ As pointed out above, for inflation targeting to be a success, institutions in the country must support independence of the central bank, as well as a strong fiscal position and sound financial system. Before embarking on inflation targeting, Chile passed new central bank legislation in 1989 (that took effect in 1990), which gave independence to the central bank and mandated price stability as one of its primary objectives. ${ }^{2}$ A sound fiscal policy was also in place, with the fiscal balance in surplus in every year from 1991 to 1997 . In addition, due largely to the measures taken in the aftermath of its severe banking crisis in the early 1980s, Chile's standards and practices in the areas of banking regulation and supervision were of a quality comparable to those found in industrialized countries.

Chile's central bank was well aware of the difficulty of controlling inflation and precisely hitting the target when inflation was in the double digits, and it dealt with this problem in several ways. First, like the industrialized countries that have adopted inflation targeting (see Bernanke, et. al, 1999), Chile phased in inflation targeting gradually after initial successes in lowering inflation. When the inflation objective was first announced in September 1990, it was interpreted more as official inflation projections rather than as formal or "hard" targets. Only after the central bank experienced success in both meeting the inflation objectives and lowering inflation, did it begin to emphasize that the inflation objectives should be interpreted as hard targets for which the central bank would be accountable (Felipe Morande and Klaus Schmidt-Hebbel, 1997). Second, Chile's central bank pursued a very gradualist approach to lowering its inflation objectives, 
starting with targets of over $20 \%$ for 1991 and lowering them slowly to $3.5 \%$ by the end of the decade. Third, because of the difficulty of controlling inflation at inflation rates which were still above $10 \%$, a realistic range for the inflation outcomes would have been very large. Thus, as part of the process of hardening the inflation targets, the Chile's central bank switched from target ranges to point targets with its announcement in September 1994 for the 1995 objective.

The Chilean experience with inflation targeting looks quite successful. Inflation fell from levels above $20 \%$, when inflation projections were first introduced, to a level around $3 \%$ at present. Over the same period, output growth was very high, averaging more than $8 \%$ per year from 1991 to 1997, a level comparable to those exhibited by the (former) Asian tigers. Only in the last two years has the economy entered a recession with output growth falling to $3.4 \%$ in 1998 and to a $-2.9 \%$ rate for the first half of 1999 . In 1998 the Chilean central bank was reluctant to ease monetary policy and let the exchange rate depreciate in order to cushion the effects of a large, negative terms of trade shock. Instead, the Chilean central bank raised interest rates and even narrowed the exchange rate band. In hindsight, these decisions appear to have been a mistake: the inflation target was undershot and the economy entered a recession for the first time in more than 15 years. Not surprisingly, the central bank came under increased criticism and in 1999 reversed course, by lowering interest rates and allowing the peso to depreciate.

The Chilean example suggests that inflation targeting can be used as a successful strategy for gradual disinflation in emerging market countries, even when initial inflation is on the order of 20\%. It is important to emphasize that the success of inflation targeting cannot be solely attributed to the actions of the Chilean central bank: supportive policies such as absence of large fiscal deficits and rigorous regulation and supervision of the financial sector have been 
crucial to its success. ${ }^{3}$ Another important element of Chile's strategy has been a gradual hardening of the targets over time. However, the experience in Chile of the last two years, as well as that of industrialized countries, indicates that a key requirement for successful inflation-targeting regimes in emerging market economies is the recognition that undershooting inflation targets is just as costly as overshooting the targets. Support for an independent central bank which is pursuing price stability can erode if the central bank is perceived as focusing solely on lowering inflation to the detriment of other objectives such as minimizing output variability.

In addition, Chile has not yet fully accomplished a full-fledged, inflation targeting regime. The Chilean central bank has not yet produced an Inflation Report- type of document, nor does it publish inflation forecasts; the accountability mechanisms of monetary policy are also weak. Brazil, on the other hand, which adopted inflation targeting in the wake of its currency crisis in early 1999 , shows that a full-fledged inflation targeting regime can be put in place remarkably quickly. Within four months of the announcement by the newly appointed central bank president that inflation targeting would be adopted, the central bank of Brazil implemented an inflation targeting regime with all the "bells and whistles" found in inflation targeters in industrialized countries, including an Inflation Report with published inflation forecasts. Despite the initial success of Brazilian inflation targeting which has kept inflation below $10 \%$ despite a substantial exchange-rate depreciation, there are still serious doubts about whether it will be ultimately successful because it is by no means clear whether Brazil can solve its deep-rooted fiscal problems.

As noted, a critical issue for inflation targeting in emerging market countries is the role 
of the exchange rate. Emerging market countries, including those engaging in inflation targeting, have rightfully been reluctant to adopt an attitude of "benign neglect" of exchange rate movements partly because of the existence of a sizable stock of foreign currency and/or a high degree of (partial) dollarization. Nonetheless, emerging market countries probably have gone too far for too long in the direction of limiting exchange rate flexibility--not only through the explicit use of exchange rate bands, but also through frequent intervention in the foreign exchange market. Responding too heavily and too frequently to movements in a "flexible" exchange rate runs the risk of transforming the exchange rate into a nominal anchor for monetary policy that takes precedence over the inflation target, at least in the eyes of the public. One possible way to avoid this problem is for inflation-targeting central banks in emerging market countries to adopt a transparent policy of smoothing short-run exchange-rate fluctuations that helps mitigate potentially destabilizing effects of abrupt exchange rate changes while making it clear to the public that they will allow exchange rates to reach their marketdetermined level over longer horizons. 


\section{References}

Bernanke, Ben S.; Laubach, Thomas; Mishkin, Frederic S. and Posen, Adam S. Inflation Targeting: Lessons from the International Experience. Princeton, NJ: Princeton University Press, 1999.

Calvo, Guillermo. “Capital Markets and the Exchange Rate," mimeo, University of Maryland, October, 1999.

Edwards, Sebastian. "How Effective are Capital Controls?" Journal of Economic Perspectives, Fall 1999, Volume 13, \#4, pp. 65-84.

Masson, Paul R., Savastano, Miguel A. and Sharma, Sunil. “The Scope for Inflation Targeting in Developing Countries,” IMF Working Paper 97/130, October, 1997.

Mishkin, Frederic S. "Understanding Financial Crises: A Developing Country Perspective," in Michael Bruno and Boris Pleskovic, eds., Annual World Bank Conference on Development Economics 1996. Washington D.C.: World Bank, 1996, pp. 29-62.

Mishkin, Frederic S. “International Experiences with Different Monetary Regimes,” Journal of Monetary Economics, 43, 1999, pp. 579-606.

Mishkin, Frederic S. and Savastano, Miguel, A. "Monetary Policy Strategies for Latin America," mimeo., November, 1999.

Mishkin, Frederic S. and Posen, Adam S. "Inflation Targeting: Lessons from Four Countries," Federal Reserve Bank of New York Economic Policy Review, August 1997: 9-110.

Morande, Felipe and Schmidt-Hebbel, Klaus. "Inflation Targets and Indexation in Chile," mimeo, Central Bank of Chile, August, 1997. 


\section{Endnotes}

* Alfred Lerner Professor of Banking and Financial Institutions, Graduate School of Business, Columbia University, and Research Associate, National Bureau of Economic Research. I thank Miguel Savastano for helpful comments. The views expressed in this paper are exclusively those of the author and not those of Columbia University or the National Bureau of Economic Research.

1. See Mishkin and Savastano (1999) for a more detailed discussion of the experience with inflation targeting in Latin America.

2. The legislation also stipulated a central bank objective to ensure equilibria in domestic and external payments. Partly because of this, Chile maintained an exchange rate band around a crawling peg during most of the 1990s. Importantly, however, the central bank made it clear that when there was a potential conflict between the exchange rate band and the inflation target, the inflation target would take precedence.

3. The Chilean controls on short-term capital flows have often been cited as another important factor behind the relative stability of the Chilean economy and the success of monetary policy, but rigorous prudential supervision was probably more important. For a recent overview of the debate surrounding Chile's capital controls, see Sebastian Edwards, 1999. 